\title{
Association between T3, T4, and TSH hormones proportion and Toxoplasma gondii anti-lgG seroprevalence in patients suffering from clinical and drug-controlled thyroid dysfunctions in southeastern Iran
}

\section{Güneydoğu İran'da klinik ve ilaç kontrollü tiroid fonksiyon bozukluğu olan hastalarda T3, T4 ve TSH hormonları oranı ile Toxoplasma gondii anti-lgG seroprevalansı arasındaki ilișki}

\begin{abstract}
Vahid RAissi ${ }^{1}$ (ID), Gita ALizADEH ${ }^{1}$ (ID), Fatemeh BAYAT ${ }^{1}$ (ID), Elham AKHLAGHi2 (ID), Muhammad GETSO ${ }^{3}$ (ID), Omid RAIESi ${ }^{4}$ (ID), Ali ABDOLLAHi ${ }^{5}$ (ID), Asma IBRAHIM ${ }^{6}$ (ID), Sakineh AKBARi ${ }^{7}$ (ID), Zahra NAVi ${ }^{1}$ (ID), Soudabeh ETEMADiं ${ }^{8}$ (ID)
\end{abstract}

\section{ABSTRACT}

Objective: Toxoplasma gondii is an important agent responsible for many hormonal and behavioral disorders in humans. The main objective of this study was to evaluate the hypothesis that ' $T$. gondii infection interferes with thyroid hormones secretion or thyroid drug treatment'.

Methods: This is a cross-sectional study that involved 249 patients suffering from thyroid dysfunctions, divided into 3 groups: hypothyroidism $(n=107)$, hyperthyroidism ( $n=96)$, and drug-controlled thyroid disorders $(\mathrm{n}=91)$, referred to Seyedoshohada Kerman private clinic. Serum samples were tested for thyroid-stimulating hormone (TSH), triiodothyronine (T3), and thyroxine (T4) along with Toxoplasma anti-lgG using ELISA technique. Demographic information was collected using a demographic sheet.

\section{ÖZET}

Amaç: Toxoplasma gondii, insanlarda birçok hormonal ve davranıșsal bozukluktan sorumlu olan önemli bir ajandır. Bu çalıșmanın temel amacı, 'T. gondii enfeksiyonunun tiroid hormonlarının salgılanmasına veya tiroid ilaç tedavisine müdahale ettiği hipotezini değerlendirmektir.

Yöntem: Bu, Seyedoshohada'daki Kerman özel kliniği'ne yönlendirilen, tiroid disfonksiyonlarından muzdarip 249 hastayı 3 gruba ayıran kesitsel bir çalıșmadır: hipotiroidizm $(\mathrm{n}=107)$, hipertiroidizm $(n=96)$ ve ilaç kontrollü tiroid bozuklukları $(n=91)$. Serum örnekleri tiroid stimulan hormon (TSH), triiyodotironin (T3) ve tiroksin (T4) ile Toksoplazma anti-IgG için ELISA tekniği kullanılarak test edildi. Demografik bilgiler bir demografik anket kullanılarak toplandı.

'Tehran University of Medical Sciences, Department of Medical Parasitology and Mycology, School of Public Health, Iran ${ }^{2}$ Kerman University of Medical Sciences, Department of Parasitology and Mycology, School of Medicine, Iran ${ }^{3}$ Bayero University, Department of Medical Microbiology and Parasitology, College of Health Sciences, Nigeria ${ }^{4}$ Ilam University of Medical Sciences, Department of Parasitology, School of Allied Medical Sciences, Iran ${ }^{5}$ Islamic Azad University, Department of Surgery, Science and Research Branch, Iran ${ }^{6}$ University of Sadat City (GEBRI, USC), Genetic Engineering and Biotechnology Research Institute, Egypt ${ }^{7}$ Isfahan University of Medical Sciences, Department of Parasitology and Mycology, School of Medicine, Iran ${ }^{8}$ Zahedan University of Medical Sciences, Resistant Tuberculosis Institute, Infectious Diseases and Tropical Medicine Research Center, Iran

İletişim / Corresponding Author : Soudabeh ETEMADí 
Results: The seroprevalence of Toxoplasma gondii IgG antibodies among patients with hypothyroidism, hyperthyroidism, and drug-controlled thyroid disorders was $22.4 \%, 19.8 \%$, and $22 \%$ respectively. The mean value of thyroid hormones of positive $T$. gondii samples in hypothyroidism, hyperthyroidism, and drug-controlled thyroid disorders was $\mathrm{TSH}=7.95, \mathrm{~T} 3=1.12, \mathrm{~T} 4=2.36$; $\mathrm{TSH}=0.14, \mathrm{~T} 3=1.42$, $\mathrm{T} 4=7.85 ;$ and $\mathrm{TSH}=2.75, \mathrm{~T} 3=1.12$, T4=1.45 respectively. The seropositivity of Toxoplasma gondii infection was $40.4 \%$ among individuals with a history of contact with pets and $26.3 \%$ among the rural dwellers.

Conclusion: There was no significant difference between $T$. gondii infection among the three study groups. A comparison of serum levels of thyroid hormones between infected and non-infected individuals in the above-mentioned groups illustrated that latent toxoplasmosis wasn't significantly associated with thyroid hormones secretion. Also, contact with pets and the rural lifestyle has a positive association with $T$. gondii seroprevalence.

Key Words: Toxoplasma gondii, hypothyroidism, hyperthyroidism, cross-sectional study, TSH, T3, T4
Bulgular: Hipotiroidizm, hipertiroidizm ve ilaç kontrollü tiroid bozukluğu olan hastalarda Toxoplasma gondii IgG antikorlarının seroprevalansı sırasıyla \%22.4, $\% 19.8$ ve \%22 idi. Hipotiroidizm, hipertiroidizm ve ilaç kontrollü tiroid bozukluklarında pozitif $T$. gondii örneklerinin tiroid hormonlarının ortalama değeri TSH ;7.95, T3;1.12, T4;2.36; TSH;0.14, T3;1.42, T4;7.85; ve sırasıyla TSH;2.75, T3;1.12, T4;1.45 idi. Toxoplasma gondii enfeksiyonunun seropozitifliği, evcil hayvanlarla temas öyküsü olan bireylerde $\% 40.4$ ve kırsalda yașayanlarda \%26.3 idi.

Sonuç: Üç çalıșma grubu arasında T. gondii enfeksiyonu arasında anlamlı bir fark yoktu. Yukarıda belirtilen gruplarda enfekte olan ve olmayan bireyler arasında serum tiroid hormon seviyelerinin karşılaștırılması, latent toksoplazmozun tiroid hormonlarının salgılanmasıyla önemli ölçüde ilișkili olmadığını gösterdi. Ayrıca, evcil hayvanlarla temas ve kırsal yașam tarzı, $T$. gondii seroprevalansı ile pozitif bir ilișkiye sahipti.

Anahtar Kelimeler: Toxoplasma gondii, hipotiroidizm, hipertiroidizm, kesitsel çalıșma, TSH, T3, T4

\section{INTRODUCTION}

Toxoplasma gondii is an obligatory intracellular parasite of worldwide distribution (1). It is an Apicomplexan protozoan that causes toxoplasmosis - an important zoonotic disease associated with high morbidity and mortality $(2,3)$. The disease is contracted essentially via the ingestion of tissue cysts in meat products or the intake of sporulated oocytes shed by cats into the environment (4). Clinical diagnosis of toxoplasmosis can be difficult since its clinical features are very similar to that of various illnesses (5). Latent toxoplasmosis is caused by the presence of tissue cysts in eyes leading to retina scars and eventual blindness (6) Infection with $T$. gondii affects about one-third of the world population. Hence its prevention, diagnosis, and management should be an essential health priority (7). In addition,complications caused by $T$. gondii have an impact on maternal abortion (8). Toxoplasma gondii is practically accepted to cause miscarriages, intrauterine deaths or congenital abnormalities only as a result of the primary acute infection of the mother. Recurrent conditions such as infection with a different genotype or the tissue cyst in the uterine wall are all rare and accepted as negligible. As a result, $T$. gondii is not considered as a cause of recurrent abortion. Generally, all organ systems could be involved with disseminated toxoplasmosis with or without specific symptoms (9-19). Recently, 
T. gondii is recognized as a target research in autoimmune thyroid diseases (20) and as a pathogen that accounts for other autoimmune diseases (8, 21, 22). Some studies illustrated that $T$. gondii is responsible for thyroid hormones alterations, consequent to changes in thyroid morphology and function; initial infection with $T$. gondii dramatically increases thyroid peroxidase $(23,24)$. Another study advocates that chronic toxoplasmosis can alter the stimulation of the hypothalamus, thus, alters T3, T4 secretion and results in TSH disturbance $(13,23)$. Based on the previous literature we hypothesized that chronic T. gondii infection can upset the serum level of thyroid hormones. Hence, the present study aimed to evaluate the serum thyroid hormones levels among members of the three study groups with thyroid dysfunctions and then compared data to that of the control (non-infected cases) in each group. Besides, the study evaluated the role of $T$. gondii in treatment of thyroid dysfunction disturbance. To our knowledge, this is the first time that the effects of $T$. gondii infection on drug treatment has been investigated among patients suffering from thyroid disorders.

\section{MATERIAL and METHOD}

This study was approved by the Zahedan University of Medical Sciences Ethics Committee (Date: 24.01.2020 and Number: IR.ZAUMS.REC.1399.486.

\section{Study Design}

This is a cross-sectional study involving 249 patients suffering from thyroid disorders hypothyroidism $(n=107)$, hyperthyroidism $(n=96)$ and drug-controlled thyroid disorders $(n=91)$ - referred to Seyedo Alshohada private clinic in Kerman city, southeastern IRAN. The study was performed between February 2018 and July 2019. All the participants gave their consent before the commencement of the study. We recorded the patients' demographic information, history about their locations, contact with pets, meat product consumption, and pica behavior by demographic sheet. We collected $5 \mathrm{~mL}$ of blood from each patient, centrifuged the blood at $3000 \mathrm{rpm}$ for 10 minutes, and then stored in 4 separate Eppendorf tubes at $-20^{\circ} \mathrm{C}$, till the next test.

Serological and Hormones Evaluations

Anti-lgG for $T$. gondii was measured using the Toxoplasma IgG ELISA kit (PISHTAZ TEB, Iran). We compared the OD of each sample with the cut-off value and recorded. We analyzed the hormones by TSH ELISA Kit (AUTOBIO- Zhengzhou, China), T3 ELISA kit (IDEAL-Tehran, Iran), and T4 ELISA Kit (AUTOBIOZhengzhou, China) according to the manufacturer's guidelines. Normal ranges of hormones kits were: TSH normal range: 0.3 - $5.5 \mu \mathrm{l} \mathrm{U} / \mathrm{ml}$, T4 normal range: $4.5-13 \mu \mathrm{g} / \mathrm{dl}$, and T3 normal range: $0.55-1.9 \mathrm{ng} / \mathrm{ml}$.

Statistics analysis

In this study, we used SPSS software version 20 for statistical analyses of our data. We compared the thyroid hormones and seroprevalence of Toxoplasma anti-lgG in the three groups (hypothyroidism, hyperthyroidism, and drug-controlled thyroid disorders) using independent sample T-test. Evaluation of independent variable efficacy (positive T. gondii anti lgG) over the dependent variables (thyroid hormones) along with the effect of demographic factors on IgG seroprevalence were assessed by multiple invariant analysis of variance (ANOVA) and Chi-Square test respectively. P-value $\leq$ 0.05 was considered significant in all the tests.

\section{RESULTS}

A total of 294 patients - referred to Seyedo Alshohada private clinic in Kerman, southeastern Iran - were recruited in this study and were divided among three groups: hypothyroidism ( $n=107)$, hyperthyroidism ( $\mathrm{n}=96)$ and drug-controlled thyroid disorders $(n=91)$. The study population consists of 135(\%54) men and 114(\%46) women. Their mean 
age was 49.4, 56.7, 41.3 years for hypothyroidism, hyperthyroidism, and drug-controlled thyroid disorders groups, respectively. Our study findings showed that T. gondii infection doesn't have a significant correlation with thyroids dysfunction. The seroprevalence of toxoplasmosis among patients with thyroid disorders was summarized in Table 1.

Table 1. Percentage distribution of Thyroid disorders patients infected with Toxoplasma by ELISA

\begin{tabular}{|c|c|c|c|c|c|c|c|}
\hline \multirow[b]{3}{*}{ Group } & \multicolumn{7}{|c|}{ ELISA test } \\
\hline & \multicolumn{2}{|c|}{ Positive IgG } & \multicolumn{2}{|c|}{ Negative IgG } & \multicolumn{2}{|c|}{ Total } & P-value \\
\hline & $N$ & $\%$ & $N$ & $\%$ & $N$ & $\%$ & \multirow{5}{*}{$P>0.05$} \\
\hline Hypothyroidism & 24 & $(22.4 \%)$ & 83 & $(77.6 \%)$ & 107 & $(36.4 \%)$ & \\
\hline Hyperthyroidism & 19 & $(19.8 \%)$ & 77 & $(80.2 \%)$ & 96 & $(32.6 \%)$ & \\
\hline Drug-controlled thyroid disorder & 20 & $(22,0 \%)$ & 71 & $(78,0 \%)$ & 91 & $(31,0 \%)$ & \\
\hline Total & 63 & $(21.4 \%)$ & 231 & $(78.6 \%)$ & 294 & $(100,0 \%)$ & \\
\hline
\end{tabular}

We compared the level of TSH, T3, T4 hormones among patients with hypothyroidism, hyperthyroidism and drug-treated thyroid dysfunction and found that there aren't significant statistical differences in hormones concentration between infected and non- infected individuals. The mean concentration of the thyroid hormones (TSH, T4, and T3) in sera of thyroid disorders patients with toxoplasmosis (IgG-positive), by age groups and gender, are shown in Table 2 and 3 .

Table 2. Association between the mean concentration of hormones (TSH, T4, and T3) in sera thyroid disorders patients with toxoplasmosis (IgG-positive) by age group, Iran

\begin{tabular}{|c|c|c|c|c|c|c|c|c|c|c|}
\hline & \multicolumn{5}{c|}{ Mean concentration of Thyroid hormones in Thyroid disorders } \\
\hline & \multicolumn{3}{|c|}{$\begin{array}{c}\text { Hypothyroidism } \\
\text { mean } \pm \text { SD }\end{array}$} & \multicolumn{3}{c|}{$\begin{array}{c}\text { Hyperthyroidism } \\
\text { mean } \pm \text { SD }\end{array}$} & \multicolumn{3}{c|}{$\begin{array}{c}\text { Drug-controlled thyroid } \\
\text { disorder mean } \pm \text { SD }\end{array}$} & $P$-value \\
\hline $\begin{array}{c}\text { Age } \\
\text { group }\end{array}$ & TSH & T4 & T3 & TSH & T4 & T3 & TSH & T4 & T3 \\
\hline $20-40$ & $7.00 \pm 0.5$ & $1.50 \pm 0.5$ & $1.00 \pm 0.5$ & $0.08 \pm 0.02$ & $7.80 \pm 2.1$ & $1.40 \pm 0.51$ & $4.25 \pm 0.35$ & $7.00 \pm 1.41$ & $1.25 \pm 0.35$ \\
\hline $41-60$ & $8.03 \pm 1.64$ & $2.53 \pm 0.71$ & $1.03 \pm 0.3$ & $0.10 \pm 0.04$ & $9.18 \pm 1.9$ & $1.15 \pm 0.46$ & $1.59 \pm 0.7$ & $7.54 \pm 2.16$ & $1.29 \pm 1.23$ \\
\hline $61 \leq$ & $8.64 \pm 1.37$ & $2.35 \pm 1.21$ & $1.14 \pm 0.47$ & $0.14 \pm 0.06$ & $7.33 \pm 0.68$ & $1.04 \pm 0.29$ & $1.85 \pm 1.13$ & $6.35 \pm 1.93$ & $0.96 \pm 0.3$ & $P>0.05$ \\
\hline
\end{tabular}

Table 3. Association between the mean concentration of hormones (TSH, T4, and T3) in sera thyroid disorders patients with toxoplasmosis (IgG-positive) by gender, Iran

\begin{tabular}{|c|c|c|c|c|c|c|c|c|c|c|}
\hline & \multicolumn{6}{c|}{ Mean concentration of Thyroid hormones in Thyroid disorders } \\
\hline & \multicolumn{3}{|c|}{$\begin{array}{c}\text { Hypothyroidism } \\
\text { mean } \pm \text { SD }\end{array}$} & \multicolumn{3}{c|}{$\begin{array}{c}\text { Hyperthyroidism } \\
\text { mean } \pm \text { SD }\end{array}$} & \multicolumn{2}{c|}{$\begin{array}{c}\text { Drug-controlled thyroid disorder } \\
\text { mean } \pm \text { SD }\end{array}$} & $P$-value \\
\hline Gender & TSH & T4 & T3 & TSH & T4 & T3 & TSH & T4 & T3 & \\
\hline male & $7.73 \pm 1.26$ & $2.26 \pm 0.79$ & $1.19 \pm 0.34$ & $0.11 \pm 0.05$ & $8.18 \pm 2.21$ & $1.06 \pm 0.39$ & $1.80 \pm 1.32$ & $7.88 \pm 2.23$ & $0.86 \pm 0.22$ & $P>0.05$ \\
\hline female & $8.66 \pm 1.78$ & $2.50 \pm 1.08$ & $1.19 \pm 0.39$ & $0.10 \pm 0.05$ & $8.27 \pm 1.55$ & $1.27 \pm 0.45$ & $2.06 \pm 1.02$ & $6.40 \pm 1.62$ & $1.43 \pm 1.20$ \\
\hline
\end{tabular}


We evaluated the demographic and behavioral factors of each participant. We found, among the Toxoplasma seropositive, that $7(20.6 \%)$ had a positive history of pica, 46 (40.4\%) had direct contact with cats, $5(35.7 \%)$ had a history of frequent raw meat consumption, and 41 (26.3\%) lived in the rural areas. However, neither history of pica nor raw meat consumption had a statistically significant association with seropositivity to $T$. gondii, while direct contact with cats and living in rural areas had a statistically significant association with seropositivity to $T$. gondii (P-value $\leq 0.05)$. The distribution and association between these factors and toxoplasma seropositivity among the study population are shown in Table 4.

Table 4. Investigation of Factors Affecting Toxoplasma seropositivity among the study populations, Iran

\begin{tabular}{|c|c|c|c|c|c|}
\hline Variables & \multicolumn{2}{|c|}{ Samples } & \multicolumn{2}{|c|}{ Positivity } & P-value \\
\hline \multicolumn{6}{|l|}{ Pica } \\
\hline Yes & 34 & $(11.6 \%)$ & 7 & $(20.6 \%)$ & \multirow{2}{*}{$P>0.05$} \\
\hline No & 260 & $(88.4 \%)$ & 52 & $(20.0 \%)$ & \\
\hline \multicolumn{6}{|l|}{ Contact with cats } \\
\hline Yes & 114 & $(38.8 \%)$ & 46 & $(40.4 \%)$ & \multirow{2}{*}{$P \leq 0.05$} \\
\hline No & 180 & $(61.2 \%)$ & 17 & $(9.4 \%)$ & \\
\hline \multicolumn{6}{|l|}{ Consumption of raw meat } \\
\hline Yes & 14 & $(4.8 \%)$ & 5 & $(35.7 \%)$ & \multirow{2}{*}{$P>0.05$} \\
\hline No & 280 & $(95.2 \%)$ & 58 & $(20.7 \%)$ & \\
\hline \multicolumn{6}{|l|}{ Location } \\
\hline Rural area & 156 & $(53.1 \%)$ & 41 & $(26.3 \%)$ & \multirow{2}{*}{$P \leq 0.05$} \\
\hline Urban area & 138 & $(46.9 \%)$ & 22 & $(16.0 \%)$ & \\
\hline
\end{tabular}

\section{DISCUSSION and CONCLUSION}

T. gondii infection affects the multi-organ functions via hormones alteration. Some studies showed a defined correlation between $T$. gondii infection and a change in testosterone, cortisol, dopamine, and other hormones secretion $(25,26)$. The objective of our study was to assess the effect of latent toxoplasmosis on thyroid hormones in hypothyroidism and hyperthyroidism. Furthermore, we evaluated whether toxoplasmosis could interfere with the drug treatment of thyroid dysfunction. Our study findings showed that $T$. gondii infection doesn't significantly affect the serum concentration of thyroid hormones among patients with thyroid dysfunction. The rates of $T$. gondii infection positivity in all study groups were approximately similar. According to our data, the seroprevalence of toxoplasmosis was higher among patients that live in rural areas. Some researchers have proven the association between toxoplasmosis and rural lifestyle with probable link to frequent contact with cats $(27,28)$. In our study, we analyzed hormone concentrations in three groups by their age and gender subgroups, there wasn't a significant difference in hormone concentrations in different subgroups. Some studies claim that $T$. gondii has a protective role in hypothyroidism in patients less than 50 years old and suggested that it can be used to treat hypothyroidism (15). In contrast to the previous study, a survey of dogs suffering from thyroid dysfunctions reported two positive cases of toxoplasmosis that developed hypothyroidism six 
months after treatment (23). In this study, latent T. gondii didn't show any correlation with thyroid dysfunction in general and results reject the hypothesis that $T$. gondii can be used to treat or ameliorate hypothyroidism. Kenova Sarka et al. corroborated our finding that latent toxoplasmosis has no association with thyroid hormones alteration. Moreover, they observed a mild decrease in TSH and an increase in T4 secretion in pregnant women infected with T. gondii (29). This little alteration of hormones might be related to HCG hormones in pregnant women, which has a TSH-like effect causing temporary gestational hyperthyroidism in pregnancy (30). A significant decline in T4 and an increase in T3 and TSH hormones were reported in pregnant women who had miscarriage from chronic toxoplasmosis (31). Also, another research confirmed that non-pregnant women with toxoplasmosis have significantly lower serum levels of TSH in comparison to non-infected control group, whereas, there weren't difference in T3 and T4 (32). Salman and Mustafa (2014), claimed that $T$. gondii infection could decrease levels of thyroid hormones (33). Mice infected with T. gondii
Curnell strains showed a decline in serum thyroxine (T4) levels (34). Furthermore, an impaired thyroid function was recorded in murine infected by $T$. gondii. A decline in serum thyroxine (T4) occurs in NYLAR female mice infected with T. gondii (35). Controversial results of our and other's study findings show that the association of toxoplasmosis with thyroid dysfunction remains in darkness. Although in our survey we didn't find any relation between chronic toxoplasmosis and thyroid hormones alteration, further research will needed to evaluate the actual mechanism of interaction between $T$. gondii infection and thyroid dysfunction.

In conclusion, our study illustrated that the presence of toxoplasmosis infection doesn't significantly alter thyroid hormones secretion in patients with thyroid disease. Due to the approximately similar mean proportion of TSH, T3 and T4 hormones in hypothyroidism and hyperthyroidism and the control groups. We can conclude that the infection with $T$. gondii had no specific role in the disturbance of serum levels of thyroid hormones.

\section{ETHICS COMITTEE APPROVAL}

* The study was approved by the Zahedan University of Medical Sciences Ethics Committee (Date: : 24.01.2020 and Number: IR.ZAUMS.REC.1399.486).

\section{CONFLICT OF INTEREST}

The authors declare no conflict of interest. 


\section{REFERENCES}

1. Raissi V, Bayat F, Taghipour A, Raiesi O, Ibrahim A, Getso M, Hoseiny Z, Alizadeh G, Shahraki MK, Etemadi S. Seroepidemiology and risk factors of toxoplasmosis among children age ranged from 1 to 14 years referred to medical diagnostic laboratories in Southeast Iran. Clin Epidemiol Glob Health. 2019 Dec 23.

2. Raissi V, Taghipour A, Navi Z, Etemadi S, Sohrabi Z, Sohrabi N, Getso M, Shamsaei S, Fasihi Karami M, Raiesi O. Seroprevalence of Toxoplasma gondii and Toxocara spp. infections among pregnant women with and without previous abortions in the west of Iran. J Obstet Gynaecol Res. 2020 Mar;46(3):382-8.

3. Karami MF, Rafiei A, Raiesi O, Getso M, Akhlaghi E, Jalali P, Shayanfard M, Beigzadeh E, Arbat SK, Mirabedini Z, Raissi V. The relation between toxocariasis and toxoplasmosis co-infection and the presence of Rheumatoid Factor (RF) in people with hydatidosis in Southwestern Iran, from 2013 to 2018. J Parasit Dis. 2019 Sep 1;43(3):379-84.

4. Eskandarian A, Jahani $\mathrm{S}$, Hejazi H, Yousefi H, Raissi V. Investigation of Toxoplasma gondii infection in cutaneous leishmaniasis patients of the Isfahan province. Int J Infect. 2017 Jan 1;4(2).

5. Dard C, Fricker-Hidalgo $\mathrm{H}$, Brenier-Pinchart $M-P$, Pelloux $\mathrm{H}$. Relevance of and new developments in serology for toxoplasmosis. Trends parasitol. 2016;32(6):492-506.

6. Bosch-Driessen LE, Berendschot TT, Ongkosuwito JV, Rothova A. Ocular toxoplasmosis: Clinical features and prognosis of 154 patients. Ophthalmology. 2002;109(5):869-78.

7. Saadatnia G, Golkar M. A review on human toxoplasmosis. Scand J Infect Dis. 2012;44(11):8051.

8. Abdoli A, Dalimi A, Soltanghoraee H, Ghaffarifar F. Molecular detection and genotypic characterization of Toxoplasma gondii in paraffinembedded fetoplacental tissues of women with recurrent spontaneous abortion. I J Fertil Steril. 2017;10(4):327.

9. Liu D, Lin C, Seshan V. AIDS complicated with disseminated toxoplasmosis: a pathological study of 9 autopsy cases. Zhonghua Bing Li Xue Za Zhi, (Chinese journal of pathology) 1994;23(3):166-9.
10. Cohn JA, McMeeking A, Cohen W, Jacobs J, Holzman RS. Evaluation of the policy of empiric treatment of suspected Toxoplasma encephalitis in patients with the acquired immunodeficiency syndrome. Am J Med. 1989;86(5):521-7.

11. Passos LN, Araújo Filho OFd, Andrade Junior HFd. Toxoplasma encephalitis in AIDS patients in Sao Paulo during 1988 and 1991. A comparative retrospective analysis. Rev Inst Med Trop São Paulo. 2000;42(3):141-5.

12. Kusbeci OY, Miman O, Yaman M, Aktepe OC, Yazar S. Could Toxoplasma gondii have any role in Alzheimer disease? Alzheimer Dis Assoc Disord. $2011 ; 25(1): 1-3$

13. Torrey EF, Bartko JJ, Yolken RH. Toxoplasma gondii and other risk factors for schizophrenia: an update. Schizophr Bull. 2012;38(3):642-7.

14. Dalimi A, Abdoli A. Latent toxoplasmosis and human. Iran J Parasitol. 2012;7(1):1.

15. Alvarado-Esquivel C, Ramos-Nevarez A, GuidoArreola CA, Cerrillo-Soto SM, Perez-Alamos AR, Estrada-Martinez S, et al. Association between Toxoplasma gondii infection and thyroid dysfunction: a case-control seroprevalence study. BMC Infect Dis. 2019;19(1):826.

16. Alvarado-Esquivel C, Sánchez-Anguiano LF, Hernández-Tinoco J, Berumen-Segovia LO, TorresPrieto YE, Estrada-Martínez S, et al. Toxoplasma gondii infection and depression: a case-control seroprevalence study. Eur J Microbiol Immunol. 2016;6(2):85-9.

17. Ivarado-Esquivel C, Sanchez-Anguiano LF, Hernandez-Tinoco J, Berumen-Segovia LO, TorresPrieto YE, Estrada-Martinez S, et al. Toxoplasma gondii infection and mixed anxiety and depressive disorder: a case-control seroprevalence study in Durango, Mexico. J Clin Med Res. 2016;8(7):519.

18. Chen X, Chen B, Hou X, Zheng C, Yang X, Ke J, et al. Association between Toxoplasma gondii infection and psychiatric disorders in Zhejiang, Southeastern China. Acta Trop. 2019;192:82-6. 
19. Shiadeh MN, Rostami A, Pearce B, Gholipourmalekabadi M, Newport DJ, Danesh $M$, et al. The correlation between Toxoplasma gondii infection and prenatal depression in pregnant women. Eur J Clin Microbiol Infect Dis. 2016;35(11):1829-35.

20. Benvenga S, Guarneri F. Molecular mimicry and autoimmune thyroid disease. Rev Endocr Metab Disord. 2016;17(4):485-98.

21. Prandota J. Possible critical role of latent chronic Toxoplasma gondii infection in triggering, development and persistence of autoimmune diseases. Int J Neurology Resh. 2018;4(1):379-463.

22. Rivera-Correa J, Rodriguez A. Divergent roles of antiself antibodies during infection. Trends immunol. 2018;39(7):515-22.

23. Castillo VA, Gámbaro G, Sinatra V. Toxoplasmosis as a cause of subacute thyroiditis in dogs. REDVET. 2006;7(3):1-11.

24. Wasserman EE, Nelson K, Rose NR, Rhode C, Pillion JP, Seaberg E, et al. Infection and thyroid autoimmunity: A seroepidemiologic study of TPOaAb. Autoimmunity. 2009;42(5):439-46.

25. Mahbodfar HR, Yousefi Razin E, Saki J, Rafie A, Khademvatan S. Study of latent Toxoplasma gondii role in level of testosterone, DHEA, cortisol and prolactin hormones of young persons. Asian J Epidemiol. 2015;8(3):64-71.

26. Flegr J, Lindová J, Kodym P. Sex-dependent toxoplasmosis-associated differences in testosterone concentration in humans. Parasitology. 2008;135(4):427-31.

27. Kolbekova P, Kourbatova E, Novotna M, Kodym P, Flegr J. New and old risk-factors for Toxoplasma gondii infection: prospective cross-sectional study among military personnel in the Czech Republic. Clin Microbiol Infect. 2007;13(10):1012-7.
28. Stray-Pedersen B, Lorentzen-Styr A-M. The prevalence of toxoplasma antibodies among 11 736 pregnant women in Norway. Scand J Infect Dis. 1979;11(2):159-65.

29. Kaňková Š, Prochazkova L, Flegr J, Calda P, Springer D, Potlukova E. Effects of latent toxoplasmosis on autoimmune thyroid diseases in pregnancy. PloS one. 2014;9(10):e110878.

30. Glinoer D, Nayer PD, Bourdoux P, Lemone M, Robyn C, Steirteghem AV, et al. Regulation of maternal thyroid during pregnancy. J Clin Endocrinol Metab. 1990;71(2):276-87.

31. Al-Khamesi MB. Effect of Toxoplasmosis on lipid profile and thyroid hormones in aborted women. J Al-Nahrain Univ. 2016;19(4):122-6.

32. Al-Kurdy MJ, Al-Bdairi TA, Jawad TI, Amana AM. Serological detection of Toxoplasma gondii antibodies and its effect on thyroid function in non-pregnant women. Int $\mathrm{J}$ Sci Technol. 2015;143(2013):1-11.

33. Salman Y, Mustafa WG. Correlation between Toxoplasma gondii and thyroid function hormone levels in sera of patients attending private clinics and laboratories in Kirkuk City. Int J Curr Res Biosci Plant Biol. 2014;1(4):27-34.

34. Galván-Ramírez MdLL, Gutiérrez-Maldonado AF, Verduzco-Grijalva F, Jiménez JMD. The role of hormones on Toxoplasma gondii infection: a systematic review. Front Microbiol. 2014;5:503.

35. Stahl W, Kaneda Y. Impaired thyroid function in murine toxoplasmosis. Parasitology. 1998;117(3):217-22. 